\title{
The Katyn Case in Russian-Language WebPages
}

Mariya Melentyeva, University of Alberta

\begin{abstract}
About 26,000 Polish officers, enlisted men and political prisoners killed by the Soviet security services in the spring of 1940 are regarded victims of the Katyn crime. The Katyn case has influenced official Russian-Polish relations and the commemoration of the victims plays a significant role in creating Polish and Russian national ideologies. In recent years, the Russian internet has become a widely used space for public and academic debates on the matter. This paper discusses what the Russian-speaking reader can find about the Katyn massacre in Russian online. It analyzes the rhetoric of exemplary articles, forums, and films, the questions they address, and the ideas they advocate.
\end{abstract}

\section{Introduction}

For a long time, the word Katyn has been a collective name. Initially, it was related to the tragic events in the spring of 1940, when Polish officers and enlisted men were killed by the NKVD, ${ }^{1}$ Soviet security services, in the Katyn forest (near the city of Smolensk, Russia). Later, Katyn also

\footnotetext{
1 The NKVD (Narodnyi Komissariat Vnutrennikh Del), People's Commissariat of Internal Affairs, was security and political police in the Soviet Union at that time.

Past Imperfect 
encompassed other incidents such as the murder of Polish prisoners of war from the Starobelsk prison (Kharkiv province, Ukraine) and Ostashkov prison (Tver province, Russia). Fifty years after the events, approximately 26,000 Polish officers, enlisted men and political prisoners are regarded as victims of the Katyn crime. ${ }^{2}$

The Katyn case has been used as a political, national, and ideological symbol in Poland. It became a thorny subject in the Soviet Union and Russia as it raised the question of responsibility and guilt for what happened. For many Poles, Katyn became a family story, which does not lose its significance even today. Relatives of the victims were not informed about the fate of the perished and were not allowed to openly commemorate the death of their loved ones. They also did not know where the victims were buried. 3 Starting from the period of perestroika, the leadership of the Soviet Union began to disclose piecemeal information. Being a heated topic of public discussion and subject to historical research and diplomatic debates, the Katyn case continues to influence official Polish-Russian relations. From both the Russian and Polish perspective, interpretations of the events and the commemoration of the Polish victims plays a significant role in creating Polish and Russian national ideologies and in building public opinion.

\footnotetext{
2 Frank Fox, "Jewish victims of the Katyn massacre," East European Jewish Affairs, vol.23, no. 1, (1993): 49.

3 Teresa Plewak, "Katyn 60 Years On: Uncovering a Stalinist Massacre" (MA thesis, University of Alberta, 2000), 82.
} 
In April 1990, president of the USSR Mikhail Gorbachev released the NKVD lists of Polish prisoners and some accompanying documents. These were followed in October 1992 with the Russian president Boris Yeltsin's release of the remainder of the documents. These revealed Josef Stalin's and the chief of the NKVD Lavrentii Beria's responsibility for the crime, as well as the culpability of leading members of the Politburo. ${ }^{4}$ These materials were, within weeks, published in Polish and later in Russian, allowing many researchers to investigate the case and contribute to public discussion. Currently, one can find those documents and scanned images on the internet. ${ }^{5}$ In recent years, the Russian internet has also become a widely used space for public as well as academic debate on the matter. As a result, the polemic in the Russian press has grown increasingly polarized.

The Katyn massacre, as complicated and controversial as it is, requires caution and integrity from professional historians and journalists who examine this issue and publicize their findings. With a basic understanding of nuanced history and debate surrounding the Katyn massacre, my paper will approach contemporary views on the subject found on the Internet. More important than hard historical facts are the critical interpretations of the events that happened, which resurface in current debates. Those interpretations and discussions which the

\footnotetext{
4 Katyn. Mart 1940 - Sentiabr' 2000. Documenty, ed. V.P.Kozlov, (Moscow: Ves' Mir, 2001), 444.

5 Katyn: Plenniki neob'iavlennoi voiny, ed. A. N. Iakovlev, (Moscow:

Mezhdunarodnyi Fond Demokratiia, 1999). 
Russian-speaking reader can find, read and watch about the Katyn massacre on the Russian-language internet will be my primary.

I will analyze the rhetoric of articles, the questions they address, and the ideas they advocate. I argue that although there are numerous debates on the topic in the Russian-language internet, few of them can lead to a consensus among Russian readers as to how to approach the Katyn case. I observe that debates available on the internet can serve as a valuable source for analysis of attitudes of the Russian public towards its past. Besides, it shows that the Soviet past does play a vital role for the public. Many readers of public forums address the issue of Russia's responsibility for events of the Soviet period. They also admit the importance of unbiased interpretations of the Katyn case for the current political relations between Russia and Poland. My analysis reveals that it is not productive to examine the Katyn case from the perspective of Moscow or Polish victims, as the more complex picture can be obscured with collective notions of "Poles," "Russians," and "Stalinist state."

The paper consists of four parts. It starts with a brief analysis of the Katyn memorial's official website and observation of internet collections of links and primary sources. In the second part I analyze non-governmental and journalistic sites' corpuses.One can roughly divide those sites into two categories: those that defend Russia's (the Soviet Union's) innocence concerning Katyn and those whose authors consider the documents released by the Yeltsin government proof that the Soviet leadership 
organized the execution of the Polish prisoners in 1940. The paper does not intend to single out these two tendencies as independent from each other. On the contrary, the balance of opinions is quite fluid; though some may use arguments and concerns as a form of reconciliation between Polish and Russian sides, others apply the same arguments in illustrating Russophobe |197 attitudes.

I analyze lately published articles on the recent films about Katyn by the Polish producer Andrzej Wajda and by the Russian writer and editor of the newspapers $K$ bar'eru! (To the fight!), Yuri Mukhin. Finally, I provide brief comments on several online forums. The conclusion of the paper will deal with the problems and questions which I will reveal in the course of analysis. In particular, although there are some thorough scholarly works on the Katyn case available in Russian and some important political steps were made to pay last respects to the victims of the Katyn massacre, there seem to be little agreement among the ordinary internet users as to interpretations of the events. The break between scholarly findings and public awareness of those findings suggests that some important educational measures, for instance, at the secondary school level can be taken to make academic achievements available for the public.

\section{The Katyn case in Russian language representations}

Although the Russian authorities do not recognize the Katyn massacre as a enocide against the Polish people, 
the Katyn memorial's official website opens with an epigraph which indirectly categorizes the Katyn massacre as such: "The Katyn forest became a symbol of martyrdom and the power of fate which each person faced under genocide." 6 The epigraph also refers to the peoples affected. The introduction to the Russian version of the site elaborates that in the graves of the Katyn forest, tens of thousands of Soviet people who fell victim to political repression in the USSR between 1937 and 1953, in addition to more than four thousand Polish military personnel were buried. ${ }^{7}$ Admittedly, the site does not confuse the 1940 Katyn massacre with Stalinist repressions, and presents the Polish tragedy on its own. Similarly, the position of the memorial administration is stated unambiguously; the responsibility of the Soviet authorities for deciding to "liquidate" 25,700 Poles was confirmed by documents which the President of the Russian Federation Boris Yeltsin turned over to the President of the Republic of Poland Lech Walesa. ${ }^{8}$ There are no open forums or public discussions at the Katyn memorial website, only three outdated articles: two from the newspapers Komsomol'skaia Pravda (from 1990), and one from Nasha Smena (2000). Ironically, all three articles maintain that it is vital for society to conduct open discussions on the Katyn crime, even if the official legal investigation has not yet been completed. As such, this

\footnotetext{
${ }^{6}$ Memorial “Katyn," http://admin.smolensk.ru/history/katyn/index.htm (accessed February 6, 2009).

${ }^{7}$ Polish and English versions are envisioned in the structure of the site but they have not launched.

8 "Istoriia sozdaniia memoriala," Memorial "Katyn,"

http://admin.smolensk.ru/history/katyn/history.htm (accessed February 6, 2009).
} 
website is a good place to learn some basic information about the Katyn massacre; however, it provides neither any space for debates and open questions, nor any links for private and non-governmental organizational websites.

There are several sites devoted to publishing the texts and images that represent Katyn's primary sources. The most extensive is a site launched in 1999 by Yuri Krasil'nikov. ${ }^{9}$ The site is known in online sources as "Katyn, Yuri Krasil'nikov's site." The author gathered a considerable number of documents and links to research papers and online dictionary articles. The site contains testimonies and memoirs regarding Katyn, as well as maps and photographs of the massacre sites from 1943 to 1944. One can find many details about the official investigation into the case, online texts of published books, print newspapers and journal articles related to the Katyn debates. There is a copy of "The Report of the Burdenko Commission", published in the newspaper Pravda on 26 January 1944, ${ }^{10}$ and the testimonies of Jozef Mackiewicz from his book Katyn, in which the author discusses his visit to the Katyn forest in May of 1943. ${ }^{11}$ Both the aforementioned sources present two different points of view on the Katyn massacre: the report of the Burdenko Commission championed the opinion that the German Nazis committed the Katyn crimes, whereas Mackiewicz

\footnotetext{
9 Yuri Krasil'nikov, Katyn, http://katyn.codis.ru (accessed February 6, 2009).

10 Ibid.

11 Ibid. While writing this paper, I had this book at my disposal and was able to compare the materials published on Krasil'nikov's site and the text of Jozef Mackiewiecz book. Josef Mackiewicz, "Moi Katynskiie otkrytiia” in Katyn, (London, Canada: Zaria Publishing Inc., 1988). 
argues that it was the Bolsheviks who did it. In fact, Krasil'nikov's site is one of the few that provides the Russian-speaking reader with the opinions and arguments of Polish writers and journalists from published books and monographs. There are also online copies of several monographs by Russian historians, including Natalia Lebedeva's Katyn: Prestuplenie protiv chelovechestva ${ }^{12}$ (Katyn: A Crime against Humanity).

I omitted some valuable sources in the present analysis. For instance, the website Biblioteka po Katynskomu delu ${ }^{13}$ (The Library on the Katyn case) is one of them. It contains entire books in portable document format such as Katyn: Plenniki neob'iavlennoi voiny (Katyn: Prisoners of the Undeclared War) edited by Aleksandr Iakovlev ${ }^{14}$ and Katyn. 1940-2000. Dokumenty (Katyn. 19402000. Documents), drafted by Natalya Lebedeva. ${ }^{15}$ In fact, the site is a great source for a Russian-language reader as many of the books appeared in print in small numbers. Some books in this library are collections of articles by both Russian and Polish authors, which present well-balanced analysis on the topic. However, those sources are beyond the scope of this paper as they are printed books each of them can serve as a subject on its own.

12 Natalia Lebedeva, Anna Cienciala and Wojciech Materski have just published their new book Katyn: A Crime Without Punishment, (Yale University Press, 2008).

13 Biblioteka po Katynskomu delu, http://katynbooks.narod.ru (accessed February 6, 2009).

${ }^{14}$ Katyn: Plenniki neob'iavlennoi voiny, ed. A. N. Iakovlev, (Moscow:

Mezhdunarodnyi Fond Demokratiia, 1999).

15 Katyn. 1940-2000. Documents, drafted by N. S. Lebedeva, (Moscow: Ves' Mir, 2001).

\footnotetext{
15 [2009) | ( ) | ISSN 1711-053X | elSSN 1718-4487
} 


\section{Political essays and journalistic investigations}

Another type of websites is those that publish political essays and journalistic investigations. An example of these is the website, Pravda o Katyni: Nezavisimoie Rassledovaniie or The Truth about Katyn: An Independent Investigation. ${ }^{16}$ ) Its materials act as a source for many other websites. The authors of the publications are mainly journalists and publicists, such as Sergei Strysin and Vladislav Shved. Their opponents are often journalists like Natalia Gorbanevskaia and Nikolai Gladkih and historians who include Arsenii Roginskii, chair of the Memorial society. This group also includes scholars in other fields, such as Aleksei Pamiatnykh, a mathematician. This site also has partners whose rhetoric and positions are very similar to its own. ${ }^{17}$ The home page states that the organizers' aim is to "discover real facts about the Katyn matter, using the internet's potential... [to] treat critically the official interpretation of the Katyn case, which proves to be dominant in today's Russia, Poland, and other countries."18 They also advocate a balanced analysis of this complex crime, and agree that the comparison of alternative interpretations is required. ${ }^{19}$

16 Pravda o Katyni: Nezavisimoie Rassledovaniie, http://katyn.ru (accessed February 6, 2009).

17 One of these partners is the Internet-newspaper Duel' http://www.duel.ru (accessed February 6, 2009) and the online book and video store Delokrat http://www.delocrat.ru (accessed February 6, 2009).

18 Pravda o Katyni, http://katyn.ru/index.php?go=Page\&id=10 (accessed April 17, 2008).

19 Ibid. 
How do site organizers achieve their goal? The most recent publication dated January 17, 2008 is Eshche raz $o$ zapiske Beria ${ }^{20}$ (One more time about Beria's note), by Vladislav Shved. The note in question is a memorandum which Beria, head of the NKVD, addressed to Stalin. In it, Beria proposed to investigate the cases of 14,700 Polish prisoners and 11,000 intelligence officers, landlords, former officers, policemen, and defectors, who were imprisoned in Western Belorussia and Ukraine, and sentence them to execution. In his publication, Shved refutes the authenticity of Beria's note and dismisses the argument of his opponent Aleksei Pamiatnykh. Shved speaks ironically about Pamiatnykh's attention to minor and, therefore, secondary details, which, in Shved's opinion, should not be used as proofs of either version. The publicist also criticizes the style of Pamiatnykh's writing and accuses Pamiatnykh of plagiarizing the Polish historian Andrzej Nowak because he considers Pamiatnykh intellectually incapable of analyzing complex issues. In general, Shved's style and language are rude in form; he refutes any interpretations of the Katyn case that might lead to holding the Soviet authorities responsible for the Katyn massacre.

Together with Sergei Strygin, Shved wrote the article Davno Zabytyi Genotsid ${ }^{21}$ (A Long Forgotten Genocide), dated 14 June 2006. In the article, the authors

20 Vladislav Shved, "Eshche raz o zapiske Beria," http://katyn.ru/index.php?go=Pages\&in=view\&id=932 (accessed April 17, 2008).

Vladislav Shved, Sergei Strygin, "Davno Zabytyi Genotsid,"

http://zavtra.ru/cgi//veil//data/zavtra/06/656/52.html (accessed February 6, 2009).

Past Imperfect 
juxtapose two cases - the Katyn crimes and the imprisonment of Red Army troops in Polish camps between 1919 and 1922 - and present their own interpretation of Polish-Soviet relations on the basis of the published collection of documents Krasnoarmeitsy $v$ pol'skom plenu 1919 - 1922 gg.: sbornik dokumentov i materialov (Red Army men in the Polish captivity 1919-1922: a synopsis of documents and materials). ${ }^{22}$ In fact, they functionally put aside the events of Katyn, and focus on Polish hatred towards the Red Army soldiers; the way the Poles treated the 'Bolshevik' prisoners is depicted as organically pertinent to Polish society: prisoners were being physically maltreated and starved to death and sanitary conditions were poor.

Their detailed article frequently quotes the documents from the aforementioned collection and, on a number of occasions insists that the number of victims was, in reality, much higher than that presented in the book (the article does not mention what number the book gives): the authors state that in just the two Polish prisoner-of-war camps of Tuchola and Strzalkowo died 22000 and 12000 Red Army men correspondingly. Apparently, Shved and Strygin's analysis is intended to underscore the horrors of Polish prison in order to dwarf the tragedy of the Katyn massacre. This flawed comparison shows that the authors have political issues on their own research agenda. The conclusions increase the contrasting effect of the article

22 Krasnoarmeitsy v pol'skom plenu 1919 - 1922 gg.: sbornik dokumentov $i$ materialov, ed. by N.E.Ieliseieva, (Moscow: Rossiiskii gos. voennyi arkhiv, 2004). 
since the authors assert that the Polish antipathy towards the Red Army prisoners proves that Polish soldiers exterminated these prisoners deliberately. Thus, the authors insist, the death of the Red Army soldiers in 1919 to 1922 in Polish camps was genocide.

The Katyn massacres have remained an important topic in the publications of the Memorial society, an historical and human rights society in the Soviet Union and later a union of regional organizations. ${ }^{23}$ The Memorial society often organizes cultural events concerning unsolved human rights issues. Its official site ${ }^{24}$ and the online newspaper Polit.ru ${ }^{25}$ cover these events. For example, on 26 March 2008, Arsenii Roginskii, chair of the Memorial society, in his letter to the Chief Prosecutor of the Russian Federation Yuri Chaika requested the rights to publish the resolution of the Chief Military Prosecutor's Office (Glavnaia voennaia prokuratura) on the Katyn case. This contains the results of the official investigation and the names of offenders. The Memorial Society actively challenges the current Russian government to continue its investigation into the Katyn tragedy, and to complete this case not only from a legal perspective but also from a political one; to disclose the legal conclusions and to firmly recognize the Soviet authorities' responsibility for the murders.

In particular, among its publications are those written by Natalia Gorbanevskaia, a poet, journalist, and,

23 Organized in the 1980s, the Memorial society was officially founded in 1992.

${ }^{24}$ Prava cheloveka v Rossii, http://hro.org/ (accessed February 06, 2009).

25 Polit.ru, http://www.polit.ru/ (accessed February 06, 2009). 
from the late 1960s, human rights activist in the Soviet Union. She emigrated from the Soviet Union in 1975 but continued her human rights activity in Paris and Warsaw. Gorbanevskaia has written on the Katyn case on many occasions and discussed the topic using Russian and Polish sources. She wrote an article for the fortieth anniversary of the events of Katyn in 1980 and another one for the sixtyfifth anniversary in 2005. The latter is a survey of the subject available on Russian-language webpages. ${ }^{26}$ She finds that Katyn remains topical as a subject for the Russian-speaking internet user. Despite this interest, she finds that few are eager to refute the Soviet leadership's responsibility for the Katyn forest executions. The only major source for such refutation, Gorbanevskaia explains, are articles written by Yuri Mukhin. ${ }^{27}$ I now turn to address Mukhin's publications below.

The debates about responsibility for the Katyn massacre

On March $18^{\text {th }}$ and $19^{\text {th }}$ of 2008, the Polish director Andrzej Wajda showed his new film Katyn in Moscow. The Memorial Society participated in organizing the premiere. In his review, Nikolai Gladkikh presented a discussion

26 The summary by Gorbanevskaia served as an impetus to write this paper and analyze current online discussions. See Natalia Gorbanevskaia, "O Katyni: dvadtsat' piat' let nazad i segodnia," ("On Katyn: twenty five years ago and today") http://www.polit.ru/research/2005/03/24/katyn.html (accessed February 6, 2009).

27 This paper has already discussed essays by Shved and Strygin on Pravda $o$ Katyni site and their disagreement with the Soviet authorities' leading role in the Katyn massacre. Yuri Mukhin is currently the editor of the online newspaper Duel, an associate of Pravda o Katyni site. I will return to Mukhin's argument in the third part of my paper, in which I will discuss the online video resource. 
between the producer and the audience after the event. ${ }^{28}$ Ludmila Alekseieva, chair of the Moscow Helsinki Group, expressed her opinion on the coverage or lack thereof of the Katyn murders in Soviet media. ${ }^{29}$ She also thanked Wajda for developing interest in the topic. What is particularly interesting about Alekseieva's commentary is her perception of the film; she believed that the film raised the issue of responsibility for the Katyn crimes and shame for what "our" fellow countrymen (Soviets) had done to the Poles.

Our president [Vladimir Putin] has said recently that there is nothing that we have to apologize for and there is nobody to whom we must apologize. I am sure that the present audience thinks otherwise. There are those to whom we must apologize - the Balts [people of the Baltic region], Jews, Chechens, Kalmyks, and Czechs, Hungarians and those who perished as a result of political repressions, regardless of one's nationality. ${ }^{30}$

Alekseieva's approach towards the Katyn massacre is that there should be discussions on the subject because any lies about past political repressions and war crimes continue to do injustice and damage to the next generation.

\footnotetext{
${ }^{28}$ Nikolai Gladkikh, "Dialog o Katyni” http://hro.org/node/1589 (accessed February 06, 2009).

29 Ibid.

${ }^{30}$ Ibid.
} 
Evidently, she means that the state should not distort the collective memory of the people and that silence creates prejudice. However, her rhetoric seems dangerous in certain respects. Perhaps unintentionally, Alekseieva creates a narrative of collective responsibility; the word "we" stands for an imagined, all-encompassing community of people being held responsible for the execution of Polish officers in the Katyn forest. This is not to say that the current generation of Russians does not have anything to do with what happened to the Polish officers, in the Smolensk oblast' in 1940. Perhaps, what frightens some people is collective responsibility being perceived as personal shame, or even worse, what the state might then consider to be personal responsibility. Moreover, having opposed the constructs of "us" and "them," that is, those "to whom we must apologize - the Balts, Jews, Chechens," and so forth, - Alekseieva creates, inadvertently, another imperial construct which resurrects the Soviet identity, which helped disregard one's ethnic identity, and alienates those who fear that Russia may turn out the true successor of the Soviet Union in imposing perceptions and opinions.

Andrzej Wajda expressed gratitude to Ludmila Alekseieva for her words, but he also remarked that the film was not intended to make anybody apologize to the Polish people. "When we, the Poles, ponder over the Katyn events, we understand that the state [Stalinist] system went away forever. But in order to let something be left in the past, someone has to make a film about it."31 Again, as

31 Ibid.

Past Imperfect 15 [2009] | () | ISSN 1711-053X | elSSN 1718-4487 
in Alekseieva's commentary, one can see that a collective image of the Poles is present in Wajda's rhetoric. Such a forgiving image is equally pregnant with dangerous consequences, as the Katyn massacre is not an isolated event in Polish or Russian history. Moreover, Polish victims were not just ethnic Poles, but represented other backgrounds as well. In his article Jewish victims of the Katyn massacre, Frank Fox argues that "Jewish officers comprised 15 per cent of all the Katyn victims, a percentage higher than that of Jews in the prewar Polish population."32 Fox's article is published in English, and is not available in Russian. This example shows that more issues need to be discussed with regard to what happened in the Katyn forest, and the varied ethnicities and social strata involved. Besides the fact that imagined collective constructs can be used to simplify interpretations of events, they may also obscure the complex picture of controversial cases. It is these types of collective images of Poles and Red Army troops that Shved and Strygin employ in their interpretation of the Red Army soldiers' imprisonment in Poland in 1919 - 1922, discussed earlier.

The journalist Andrei Shcherbakov wrote a response paper to the exhibition of Wajda's film in Moscow. In his article Katyn - Amoral'noie Shou ot Andzheia Wajdy 33 (Katyn: The Amoral Show by Andrzej Wajda), published on the news website Pravda.ru, Shcherbakov accuses the

32 Frank Fox, "Jewish victims of the Katyn massacre," in East European Jewish Affairs, vol.23, no. 1, (1993): 54.

33 Andrei Shcherbakov, "Katyn - Amoral'noie Shou ot Andzheia Wajdy," http://www.pravda.ru/culture/cinema/foreigncinema/261096-0/ (accessed February 06, 2009).

Past Imperfect 15 [2009] | (C) | ISSN 1711-053X | eISSN 1718-4487 
director of demanding penitence from Russian society, and raised questions that many other online sources failed to raise. In particular, he points out that in pre-WWII Poland, anti-Semitism was quite a prevalent phenomenon. However, Shcherbakov does not invoke this in order to create a more complex picture of the Katyn events; he recalls anti-Semitism in Poland in order to hurt the Poles politically. His other examples are intended to have the same effect, that is, to compare the different tragedies and numbers of victims to show that the Poles are not to be trusted.

While the film by Wajda is not widely available for a Russian audience only the film's trailer is on YouTube. No Russian film distributor has bought rights to the film yet. The film Katynskii Detektiv (The Katyn Detective) ${ }^{34}$ by Yuri Mukhin has been available on YouTube for a number of years. In 2003, Mukhin wrote the book Antirossiiskaia Podlost'35 (The Anti-Russian Meanness) and, in 2005, he repeated his argument in his film. The content of the film is that at present, the Polish government on behalf of the relatives of Polish prisoners executed in the Katyn' forest by the NKVD demands 4 billion dollars from Russia as compensation for the massacre committed by the NKVD. The author of the film insisted that, on the contrary, the Polish officers were killed by the Nazis in 1941 and exhumed later, in 1943. In order to conceal their crime, Mukhin continued that the Nazis argued that the Polish

34 The film Katynskii Detektiv is available at http://ru.youtube.com/watch?v=9A3i80X8znc (accessed February 06, 2009).

35 Yuri Mukhin, Antirossiiskaia Podlost', (Moscow: Forum, Krymskii Most, 2003).

Past Imperfect

15 [2009] | (C) | ISSN 1711-053X | elSSN 1718-4487 
officers had been victims of the NKVD. Mukhin argues that the president of Russia Vladimir Putin had no right to agree with this Nazi fabricated lie. The target audience of Mukhin's film is the Russian Duma, deputies who, according to the director, may be able to influence the official investigation into the Katyn case and should discard the Nazi version of the events.

The film belongs to a category of discourse that is difficult to analyze due to numerous reasons. Firstly, the language used by the author is somewhat simple in nature and rather straightforward. It is even rude on occasions. For example, it contains an epigraph which reads that the "The more we pander to Poland, the more Poland wants from us." Nevertheless, here one can see that the author creates a collective image of "us" and uses it as a fundamental notion for proving his point of view. In this sense, it is similar to the argument advocated by Alekseieva, although her position is the opposite of Mukhin's; the notion of "we" traps both of them into a form of patriotic discourse. Besides this limitation, the Poles can be consequently turned into "them," another collective pronoun.

Another of Mukhin's strategies in his examination of the Katyn massacre is to create a collective image of the Polish enemy of today. He argues that the Poles stand to benefit politically if Russian leaders recognize this "Polish" version of history. In particular, he asserts that during perestroika, the "pro-Polish" Katyn case was used to destroy the Warsaw Pact, which allowed Poland to join NATO. Beyond this, Mukhin does not recognize the 
authenticity of any documents released by Gorbachev and Yeltsin, since Poland may stand to profit economically from them; Poland's main goal, Mukhin maintains, is to gain four billion dollars in reparation. Undoubtedly, in this complex situation, there always exist those who will benefit in one way or another. Using the dichotomy of "us" versus "them", Mukhin creates an illusion that Poland can benefit only to Russia's political and financial detriment.

\section{Online public forums}

Finally, some comments should be made about online public forums. A special research project can explore the rhetoric of public discussion on the Katyn massacres. Summaries, questions, answers and arguments increased dramatically in the spring of 2008, which I attribute to Wajda's presentation of his film Katyn in Moscow. Participants in Russian-language forums show very different levels of familiarity with the events of Katyn. There are those who confused Katyn with Khatyn, a Belorussian village whose residents were killed by the Nazis on 22 March 1943. On the other hand, some readers of forums are familiar with minute details of numerous interpretations of the events and could readily name the authors of the most recent publications on the topic. Below I summarize some opinions and commentaries from various forum users. Firstly, forum discussions are often fragmentary and some remarks are not illustrative, so they are not clear without context and some additional clarification. Secondly, the translation of slang and coarse 
words is a difficult linguistic task, and would not help us to understand the ideas found amongst the forum commentaries. My aim is to present some general perspective on forum debates.

The participants are often concerned with the current image of Russia and the idea that someone could force the government to pay compensation to the Poles. On the forums Riebert.info ${ }^{36}$ and Conference IXBT, ${ }^{37}$ one can read many concerns about the Russian intelligentsia's desire to apologize to the Poles for Katyn. Some forum members regard Wajda's film as a provocation against Russia on an international level, arguing that the film equates the Soviet Union and the Red Army soldiers with fascism and Nazism. One forum commentator vehemently refused to recognize Russian responsibility for any war crimes, and regarded any anti-Russian sentiment surrounding the Katyn question and World War II, as "a Nazi provocation". This reader also raised the topic of Ukrainian, Finnish, German, and Baltic (Latvian, Lithuanian, and Estonian) anti-Soviet activity, and their collaboration with the Nazis during the war. This led me to conclude that Russians should not apologize. Other commentators feel that Gorbachev and Yeltsin released the documents on the Katyn massacre solely to please the West and that they thereby betrayed Russia, even if the massacre had indeed occurred.

\footnotetext{
36 http://reibert.info/forum/showthread.php?p=353389 (accessed February 06, 2009).

${ }^{37}$ http://forum.ixbt.com/post.cgi?id=print:63:2649 (accessed February 06, 2009).
} 
On the virtual community LiveJournal, one can read a discussion on Wajda's film. ${ }^{38}$ Ironically, there is no indication that any of the forum members have actually seen the movie. The film appears to be a pretext for general conversation on the Katyn issue, and the tragic events of the Soviet past. One participant expressed the opinion that Russia has to pay compensation not only to the Poles "for Katyn," but also to Ukraine for the Holodomor (the famine of 1932-33 in Ukraine), and to the Baltic states for Soviet occupation. I think that this would correspond to practice accepted in the civilized world. An opponent to the previous statement replies that there is no sense in bringing up the Katyn topic after such a long time. I suggest an emphasis upon current problems. Some forum members regretted the Soviet period and current history books which were written from an ideologically driven perspective.

Of course, this is not the full range of Katyn case topics discussed in online Russian forums. However, it is indicative of how the participants approached issues related to Katyn. First of all, I noticed that forum members often confuse notions of state, nation, Russia and the Soviet Union. This can also be said about certain journalists, whose articles have already been analyzed. It is likely that certain people are irritated with the Katyn subject, but undoubtedly this confusion of notions and the generalization of terms; for example "the Poles" instead of "the Polish authorities," "the Poles" instead of "the families

38 http://zoil.livejournal.com/100224.html (accessed February 06, 2009). 
of the victims,"; "the Russians" instead of "the NKVD leadership," complicates consideration of the Katyn issue. Besides this caveat, there are those who see the Katyn massacre only through the prism of contemporary PolishRussian political relations. They are sometimes afraid that official Russian repentance is detrimental to the international position of Russia.

The defenders of "Russia's innocence" raised many questions related to the Katyn subject. They invoked Soviet-Polish relations, primarily those of the Russo-Polish war of 1920 and in the period before WWII, but they examined these topics from the perspective of competitive victimization. They attempted to prove that it is the Poles who have to apologize to the Russians and to thank them for the liberation of Europe from Nazi power. Thus, even this brief overview shows that the perception of the Katyn executions presented in Russian forums is somewhat confused. Many are concerned with the image of Russia's past and connect it to the Soviet past. Besides, some commentaries reveal one-sided approaches to the subject. To some extent, they can be characterized as defensive. Some of them are defensive as they can be attributed to users' personal connection to the events of World War II via their relatives. Other approaches show that readers look for the solution in the practice of the "civilized world."

\section{Conclusion}

In conclusion, this paper has presented an overview of internet sources which present, discuss, and comment on 
the executions of the Polish prisoners by Soviet security services in 1940. The subject matter is addressed on a number of online sites and through some video material available for the Russian-literate consumer. Primary sources, works by historians, and chapters from books are being preserved in online spaces. The Katyn Memorial, human rights organizations, and newspapers publish information on Katyn's official investigation and cover events related to the Katyn massacre.

I found several types of online resources on the subject. The first group of sites collects information, and serves as repositories or as online copies of documents and texts related to the events of Katyn. They also contain articles translated from Polish sources and interviews with Polish witnesses. These may be called "online libraries and archives." Secondly, there are sites which are devoted solely to debate surrounding the Katyn case; for instance, the Pravda o Katyni site. They publish journalistic and analytical articles, as well as responses to other publications about Katyn on the internet and in the press. Both types of groups can be called "private enterprises" as they were launched by individuals.

In addition to these resources, the media, nongovernmental, and public organizations often address the Katyn topic on their sites. Usually they publish political essays, analytical papers and general surveys about Katyn, often as a follow-up to government resolutions, cultural events and celebrations of anniversaries related to Katyn. On occasion, the same articles can be found on numerous websites. The Russian human rights organization, the 
"Memorial" society, appears to be among the most active; some journalists have written on the Katyn crimes since 1980s.

Informal online forums offer a great source for research on the rhetoric and opinions of ordinary people who, having come across the Katyn topic, express their views and ask questions. For many, the internet is a fast and easy way to get information and a range of opinions, so forums and other sites deserve the close consideration of historians. Definitely, some forum commentaries are simplified and biased; however, this is what makes these discussions valuable for discourse analysis. This is not to say that on the forums I found a true or full reflection of the opinions of Russian-speaking people. On the contrary, forum participants are usually comprised of specific groups which represent an insignificant portion of users of the Russian-language internet, let alone the Russian-speaking and reading population of Russia and other Russianspeaking countries.

On the whole, my paper has shown that a wide range of materials exist on the Russian-speaking internet today and the discussants employ the journalistic, analytical and informal approaches in support of their opinions. Their strategies are manifold: some present a solid analysis of numerous investigations into the Katyn executions, but draw a political conclusion with regard to Polish-Russian relations of today. Some embark on the analytical discussion, but skip over the facts and hence fail to present a balanced analysis. Others approach the Katyn massacres by presenting the historical (that is, the so called 
'age-old') hostility of the Polish people towards Russia (or the Soviet Union). Sometimes, they question arguments from the Polish side on the grounds of the alleged Polish "inner natural hatred" towards the Russian and Soviet people.

Those who take a more balanced position, taking into account opinions of different sides, frequently consider and cover the Katyn question in the press without placing it into historical context. Or, rather, they often place it into a more simplified context (the Stalinist system, the time of Great Terror, and so forth). Such an approach does not provide space for sensitive issues such as collaboration between the Poles and Ukrainians with the Nazis, as well as Jewish dimensions of the Polish army, or does not allow for a more complex understanding of the events.

I concluded that history does matter for many internet users. The debates on the Katyn case manifest, on the one hand, a profound disagreement on the understanding of the developments and, on the other hand, reveal common concerns of the participants. First, the desire to resolve the Katyn mystery characterizes positions of the Russian internet discussants. Then, the Soviet past remains relevant for the Russian readers in numerous ways, among them are Russia's current responsibility for the Soviet security services' crimes and Russian-Polish political relations today. Overall, although a significant part of scholarly research in Russian is shared in free sites with unlimited access (The Library on the Katyn case), the break between scholarly findings and public attitudes towards the Katyn case suggests that even free online access to 
those findings does not ensure their influence on the public. Some other measures, probably, addressing the Katyn crimes in history textbooks, are necessary to allow for continued dialog. 


\section{Bibliography}

Bell, Philip, "Censorship, Propaganda and Public Opinion: The Case of the Katyn Graves, 1943," Transactions of the Royal Historical Society, 5th Ser., Vol. 39. (1989).

Fox, Frank, "Jewish victims of the Katyn massacre," East |219 European Jewish Affairs, vol. 23, no. 1, (1993).

Davis, Norman and Antony Polonsky, (eds). Jews in Eastern Poland and the USSR, 1939 - 46 New York: St. Martin's Press, 1991.

Iakovlev, A.N., (ed). Katyn. Plenniki neob'iavlennoi voiny. Moscow: Mezhdunarodnyi Fond Demokratiia, 1999.

Kaczorowska, Teresa, Children of the Katyn Massacre. Jefferson, North Carolina, and London: McFarland \& Company, Inc., 2003.

Kozlov, V.P., ed. Katyn. Mart 1940 - Sentiabr' 2000. Documenty. Moscow: Ves' Mir, 2001.

Lebedeva, Natalia, drafted. Katyn. 1940-2000. Dokumenty. Moscow: Ves' Mir, 2001.

Lebedeva, Natalia, Katyn: Prestupleniie Protiv Chelovechestva. Moscow: Izdatel'skaia gruppa Progress, Kul'tura, 1994. 
Mackiewicz, Josef, Katyn. London, Canada: Zaria Publishing Inc., 1988

Plewak, Teresa. "Katyn 60 Years On: Uncovering a Stalinist Massacre." MA thesis, University of Alberta, 2000.

Werth, Alexander, Russia at War, 1941-1945. New York: Carrol \& Graf, 1984.

Online sourcesWebsites

Memorial“Katyn,"

http://admin.smolensk.ru/history/katyn/index.htm (accessed February 6, 2009).

Yuri Krasil'nikov's, Katyn, http://katyn.codis.ru (accessed February 6, 2009).

Biblioteka po Katynskomu delu, http://katynbooks.narod.ru (accessed February 6, 2009).

Pravda o Katyni: Nezavisimoie Rassledovaniie, http://katyn.ru (accessed February 6, 2009).

Duel' http://www.duel.ru (accessed February 6, 2009).

Delokrat http://www.delocrat.ru (accessed February 6, 2009). 
The Memorial society, http://hro.org/ (accessed February 6, 2009).

Polit.ru, http://www.polit.ru/ (accessed February 6, 2009).

Online articles

Shved, Vladislav. "Eshche raz o zapiske Beria."

http://katyn.ru/index.php?go=Pages\&in=view\&id=932

(accessed April 17, 2008).

Shved, Vladislav and Sergei Strygin. "Davno Zabytyi

Genotsid."

http://zavtra.ru/cgi//veil//data/zavtra/06/656/52.html

(accessed February 6, 2009).

Gorbanevskaia Natalia. "O Katyni: dvadtsat' piat' let nazad i segodnia."

http://www.polit.ru/research/2005/03/24/katyn.html

(accessed February 6, 2009).

Gladkikh, Nikolai "Dialog o Katyni,"

http://hro.org/node/1589 (accessed February 6, 2009).

Shcherbakov, Andrei. "Katyn - Amoral'noie Shou ot Andzheia Wajdy."

http://www.pravda.ru/culture/cinema/foreigncinema/26

1096-0/ (accessed February 6, 2009). 
Online Forums

Reibert forum,

http://reibert.info/forum/showthread.php?p=353389

(accessed February 6, 2009).

IXBT forum,

http://forum.ixbt.com/post.cgi?id=print:63:2649 (accessed

February 6, 2009).

Zoil [pseud.], LiveJournal,

http://zoil.livejournal.com/100224.html (accessed

February 6, 2009). 